Е. 3. Киреева

\title{
ПРАГМАТИЧЕСКИЕ ВОЗМОЖНОСТИ МЕСТОИМЕНИЯ МЫ В ОФИЦИАЛЬНЫХ ДОКУМЕНТАХ ОТЧЕТНОГО ХАРАКТЕРА
}

Кірєєва Е. 3. Прагматичні можливості займенника ми в офіційних документах звітного характеру.

У статті охарактеризовано контексти вживання займенника ми в документах звітного характеру. Розглянуто прийоми мовної демагогії, можливі в цих контекстах. Виявлено, що займенник не можна розглядати як засіб маніпулювання, оскільки це «інклюзивна» ми, у якому 2-га семантична складова завжди чітко визначена.

Ключові слова: займенник ми, офіційний документ, маніпулювання, мовна демагогія.

Киреева Е. 3. Прагматические возможности местоимения мы в официальных документах отчетного характера.

В статье охарактеризованы контексты употребления местоимения $\mathrm{Mbl}$ в документах отчетного характера. Рассмотрены приемы языковой демагогии, возможные в этих контекстах. Выявлено, что местоимение нельзя рассматривать как средство манипулирования, поскольку это «инклюзивное» $\mathrm{Mbl}$, в котором 2-я семантическая составляющая всегда четко определена.

Ключевые слова: местоимение $м ы$, официальный документ, манипулирование, языковая демагогия.

Kireeva E. Z. Pragmatic power of pronoun 'we' in official documents providing reports.

The article describes the contexts of use of the pronoun we in the reporting documents. The considered methods language of demagoguery possible in these contexts. It is revealed that the pronoun cannot be regarded as a means of manipulation, because it is 
«inclusive» we where 2nd semantic component always clearly defined.

Key words: the pronoun we, official document, manipulation, language demagoguery.

Рассмотрим употребление местоимения $м ы$ в документах отчетного характера для выявления цели этого употребления. Является ли $\mathrm{Mbl}^{-}$ отчитываюшееся средством манипулирования аудиторией, которое автор документа сознательно применяет?

Корпус текстов для анализа составляет 325 документов без учета редакций. Выбор материала обусловлен тем, что текст отчета состоит из дескриптивных высказываний, реализующих репрезентативную иллокутивную функцию, т.е. таких высказываний, которые могут быть истинными или ложными.

Рассмотрим типичные контексты употребления местоимения.

1. Предикаты в предложениях выражены глаголами абстрактной семантики: Мы продолюсили искоренять практику встраивания многоэтажек в сложившихся зонах жилой застройки <..> мы создаем механизмы поддержки частных детских садов [7].

Семный анализ значений полнознаменательных глаголов предикатов в двусоставных предложениях с подлежащим мы выявил, что эти глаголы относятся, как правило, к разряду неакциональных. Такие высказывания имеют невысокую информационную плотность. Однако в тексте содержится информация о конкретной реализации деятельности органа исполнительной власти или местного самоуправления. Рассматриваемые предложения, как правило, начинают ССЦ, предваряя конкретную информацию (выраженную в цифрах или процентах), или завершают его, подводя итоги сказанному.

В роли предиката востребованной является сочетание фазисного и полнознаменательного глагола. Активно употребляются глаголы, которые указывают на срединную фазу действия. Для сравнения: парадигма глагольных форм в ед. и мн. ч. единицы продолжсать представлена 96 ед., начинать - 23, заканчивать - 32. Такое словоупотребление отражает организацию процесса управления как действующего механизма.

2. Конструкции с $\mathrm{Mbl}$ регулярно воспроизводятся в модальных контекстах. В контексте модальности возможности предикаты употребляются в прошедшем времени; в контексте модальности долженствования предикаты употребляются в будущем времени: Депутать - избранники народа, и именно мы должны объединить вокруг себя и общественность, и политические силь, и бизнес и сделать все, чтобы плавчанам сегодня жилось лучше, чем вчера, а завтра - лучше, чем сегодня [6].

С. Е. З. Киреева, 2015.

$-276-$ 
3. Употребительны сложноподчиненные предложения с придаточным изъявительным, главное предложение которого включает предикат, выраженный глаголом психической деятельности (например, со значением мнения, предположения). Так, во фрагменте $M$ ы надеемся, что эти шаги вскоре смогут стать реальной поддержкой данного сектора районной экономики предикатом в главной части является глагол мышления с ядерным значением 'верить' [5].

Данные контексты создают благоприятные условия для манипулирования по следующим причинам: высказывания могут быть истинными или ложными; высказывания эмоционально окрашены, может присутствовать модусная часть; глаголы абстрактной семантики имеют размытые семантические границы; налицо заинтересованность автора в создании хорошего впечатления на аудиторию, поскольку отчет как итог работы отражает ее эффективность; вторая семантическая составляющая местоимения $\mathrm{Mbl}$ вследствие своей неопределенности может наполняться разным содержанием: «Mbl присоединяет к «я» нечетко определенное множество других лиц [1, с. 268-269; 3, с. 59].

Е. Шейгал замечает: «Неопределенность выступает как важнейший инструмент манипулирования и лежит в основе следующих стратегий: a) вуалирования, затушевывания нежелательной информации, что позволяет приглушить, сделать менее очевидными неприятные факты; б) мистификации, сокрытия истины (сознательное введение в заблуждение); в) анонимности, деперсонализации, как прием снятия ответственности» [9]. «Языковая демагогия» как рассмотрена в трудах П. Серио, Т. Николаевой, Т. Булыгиной, А. Шмелева, И. Граневой и др. Цель манипулятивного дискурса - скрытое воздействие на адресата для получения денег или власти [2], в контексте делового документа - власти, которая предполагает распоряжение и владение материальными благами.

Рассмотрим приемы языковой демагогии и выясним, применяет ли их автор отчета.

1 прием - «мы-изложение», когда за употреблением мы скрывается личная ответственность говорящего за свое высказывание. Рассмотрим фрагмент отчета: Mbl крайне обеспокоены состоянием дел в системе здравоохранения района и начинаем активно работать над тем, чтобы население имело возможность получить качественные медицинские услуги в учреждениях здравоохранения как на бесплатной, так и на платной основе [4].

$\mathrm{Mbl}$ употребляется в первичном референтном значении и семантически разлагается на ' $я+6 b l$ ' (мbl-»инклюзивное»), где $6 b l$ - 'орган 
местного самоуправления, представителем и руководителем которого я являюсь'. Поскольку документ имеет коллегиальный характер и речь идет об отчетной работе этого органа, такие высказывания нельзя рассматривать как манипулятивные. Пример демонстрирует другую особенность деятельности органов власти. Предикативная группа выражена кратким страдательным причастием со значением эмоционального состояния обеспокоень и сочетанием фазисного глагола, который обозначает начало действия, и акционального глагола начинаем работать. Автор демонстрирует неравнодушное отношение к проблеме и сообщает о действиях, которые будут предприняты. Употребление фазисного глагола отражает инерционность этой работы, поскольку выше есть информация о степени сложности и запущенности этой проблемы: Несмотря на незначительный рост рождаемости в 2009 году (281 ребенок, в 2008 - 263), в нашем районе смертность по-прежнему превышает рождаемость в 3,2 раза [там же].

2 прием - «навязывания пресуппозиции», когда суждение, которое необходимо доказать, подается как само собой разумеющееся. Рассмотрим фрагмент: В наших планах - дальнейшая реконструкция исторического ядра Туль,, продвижение тульских брендов. <..> Уверен, что в ближайтем будущем мы увидим принципиальные изменения в инфраструктуре $и$ индустрии туризма в нашем городе - это и новые туристические мармруты, и развитый гостиничный бизнес, и динамично развивающиеся музеи и выставочные зальл [7]. Автор с уверенностью представляет перспективу развития города как хорошую. По тексту не оговаривается, долгосрочная это перспектива или ближайшая. Употребление $м b l$ 'любой, каждый' в придаточном изъявительном предложении является нереферентным универсальным; представляется, будто адресат разделяет оптимистическую точку зрения автора, что сомнительно. Автор ставит цель - сделать акцент на том, что позитивные изменения станут возможны благодаря активной работе органа исполнительной власти, представителем и руководителем которого он является. Итак, прием навязывания пресуппозиции работает при нереферентном универсальном $\mathbf{M b l}$.

3 прием - употребление псевдоинклюзивной формы местоимения в переносных значениях. В литературе $\boldsymbol{м b l}$ включает в себя говорящего, а в расширительном значении может обозначать группу людей. В отчетах выявлено употребление местоимения $\mathrm{Mbl}$, в значение которого семантический элемент я не входит по умолчанию: При поддержке губернатора Тульской области Владимира Сергеевича Груздева впервые за 16 лет мы начали строить детские сады. <..>. В 2012 году мы приступили к ремонту городских тротуаров и мостили их плиткой [7];

(ㄷ Е. З. Киреева, 2015. 
Дворы мы будем ремонтировать в 2012 году[8]. Местоимение мы употребляется с предикатами, выраженными акциональными глаголами. Очевидно, что автор документа и орган, который он представляет, не являются фактическими исполнителями работ: глава администрации не будет строить детский сад, мостить плитку, ремонтировать дворы и т. д. Специфика управленческого труда заключается в том, что органы государственной власти и местного самоуправления инициируют управленческие решения путем принятия официальных документов. Без документов не были бы выделены средства и заключены договоры с организациями-подрядчиками. Поэтому автор позиционирует себя как исполнителя конкретных работ. С другой стороны, автор представляет решение проблемы как общего дела, возможно, для того чтобы выразить идею единения в духе принципа кооперации. Представляется, что такое употребление $\mathrm{Mbl}$ стирает грани между руководителем и исполнителем.

Итак, местоимение $\boldsymbol{M b l}$ в отчетах нельзя рассматривать как средство манипулирования. Это «инклюзивное» $\mathrm{Mbl}$, в котором 1-я семантическая составляющая - я, а 2-я - 'орган, который я представляю'. Прием навязывания пресуппозиции как средство манипулирования возможен при нереферентном универсальном $\mathrm{Mbl}$, и случаи его употребления единичны.

\section{Литература}

1. Бенвенист Э. О субъективности в языке : Общая лингвистика / Э. Бенвенист. М. : Едиториал УРСС, 2002. - 436 с.

2. Гранева И. Ю. Местоимение «мы» как средство идеологических манипуляций в русской языковой картине мира / И. Ю. Гранева // Вестник Нижегородского университета им. Н. И. Лобачевского. - 2010. - № 4(2) - С. 494-496.

3. Норман Б. Ю. Лингвистическая прагматика (на материале русского и других славянских языков) : курс лекций / Б. Ю. Норман. - Минск, 2009. - 183 с.

4. Об отчете главы администрации муниципального образования Суворовский район о деятельности администрации муниципального образования Суворовский район по решению вопросов местного значения за 2009 год : Решение Собрания представителей муниципального образования Суворовский район от 19.03.2010 N 15164 // Справочно-правовая система КонсультантПлюс : Тульский Выпуск [Электронный ресурс]. - Режим доступа : http://base.coosultaoot.ru

5. Об отчете главы администрации Щекинского района о результатах работы администрации по итогам 1-го полугодия 2009 года : Решение Собрания представителей муниципального образования Щекинский район от $16.09 .2009 \mathrm{~N} \mathrm{6/58}$ // «Щекинский вестник», 26.09.2009, N 37

6. Об отчете главы муниципального образования Плавский район за 2009 год : Решение Собрания представителей муниципального образования Плавский район от 28.05.2010 N 17/115// «Плавская новь», 05.06.2010, N 21

7.Отчет Главы муниципального образования город Тула о работе за 2012 год : 
Решение Тульской городской Думы от 24.04.2013 N 60/1329 // «Тула», 30.04.2013, N 32

8. Отчет главы муниципального образования город Тула о работе за 2011 год : Решение Тульской городской Думы от 28.03.2012 N 44/861// // Справочно-правовая система Консультант Плюс: Тульский Выпуск [Электронный ресурс]. - Режим доступа : http://base.co№sultaoot.ru

9. Шейгал Е. И. Семиотика политического дискурса: дис. ... д-ра филол. наук / Е. И. Шейгал. - Волгоград, 2000. - 431 с.

Стаття надійшла до редакиії 03.09.2015 p. 